\title{
いわゆるbronchiolo-alveolar cell
}

\section{carcinomaの臨床病理学的検討}

\section{Bronchiolo-alveolar cell carcinoma of the lung}

\section{A clinicopathological study-}

斉藤泰紀・天野＼cjkstart謙・アヌサク・ジェンプルクサワン・赤荻栄一・須田秀一 佐藤博俊・橋本邦久・仲田 祐

\begin{abstract}
抄録：bronchiolo-alveolar cell carcinoma 18例について臨床病理学的検討を行った。臨床像㧈 よび予後は, 症例により様々であったが, 組織学的に, 細胞形態, 粘液産生, 発育様式 から 4 グループに大別することにより, 病像をある程度統一的に理解し得ると考えられ た。即ち，高円柱状かつ粘液産生高度な顺細胞様形態の群は切除予後良好で，立方状な いし“くい”状で浸潤性堌殖を呈す群は切除予後がきわめて不良であった。
\end{abstract}

\section{1.はじめに}

いわゆる bronchiolo-alveolar cell carcinoma は，特徵的な組織像を呈すが，臨床上他の肺腺 癌に比べ，如何なる特徵のある病像を呈するか については明らかにされていない。著者らは， 本症の自験例について, その臨床像を分類し, 予後を検討したところ，症例により病像は多彩 であるものの組織像との間に種々の関連がみと められたので報告する。

\section{2. 検索対象および方法}

対象は，1978年 4 月までに当施設で切除ある いは開胸肺生検を施行した原発性肺癌 575 例の うち, WHO 分類 ${ }^{1)}$ に拠り組織学的にbronchiolo-alveolar cell carcinoma と診断した18例で, 主訴, 胸部レ線写真像, 治療法, 臨床経過, 予 後と共に, 肉眼的所見, 腫瘍の進展の程度を,

東北大学抗酸菌病研究所 外科学部門
また組織学的には種々の特殊染色を併用して検 討した。

\section{3. 検索成績}

(1) 症例および主訴

表 1 に示す如く, 年令は41才から74才までに 亘り，60才台が 8 例と最毛多く，男性10例，女 性 8 例で，喫煙歴を有するものが 9 例あった。 初診時の主訴は, 咳嗽が 3 例, 血痰が 2 例, 胸 痛が 2 例, 発熱が 1 例あり, 残り10例は自覚症 状がなく，集検の胸部レ線写真で発見され，精 査のため来診した。

(2) 胸部レ線写真所見

胸部レ線写真をみると（図 $1-4)$, 肺炎様陰影 を呈したものが11例，腫瘤状結節状院影が 6 例 で，多発性結節性㓌影が 1 例あった。肺炎様㓌 影は，更に，辺縁不明瞭な浸潤影 4 例と，濃度 が均質で比較的辺縁の明瞭な無気肺状影 7 例に 大別し得な。 
Table 1 Clinical findings of 18 cases with bronchiolo-alveolar cell carcinoma

\begin{tabular}{|c|c|c|c|c|c|c|c|}
\hline & Case & Sex* & Age & $\begin{array}{l}\text { Smoking } \\
\text { history }\end{array}$ & $\begin{array}{c}\text { Chief } \\
\text { complaints }\end{array}$ & $\begin{array}{c}\text { Chest X-ray } \\
\text { shadow }\end{array}$ & $\begin{array}{l}\text { Operative } \\
\text { modality** }\end{array}$ \\
\hline 1. & T.A. & M & 56 & + & - & $\begin{array}{c}\text { Pneumonia like } \\
\text { (Diffuse consolidation) }\end{array}$ & RM lobectomy \\
\hline 2. & S.S. & $\mathrm{F}$ & 65 & - & Chest pain & $\begin{array}{c}\text { Pneumonia like } \\
\text { (Diffuse consolidation) }\end{array}$ & RL lobectomy \\
\hline 3. & T.K. & $\mathrm{F}$ & 53 & - & - & $\begin{array}{c}\text { Pneumonia like } \\
\text { (Diffuse consolidation) }\end{array}$ & RL lobectomy \\
\hline 4. & M.F. & M & 50 & + & $\begin{array}{l}\text { Cough } \\
\text { Sputum }\end{array}$ & $\begin{array}{c}\text { Pneumonia like } \\
\text { (Diffuse consolidation) }\end{array}$ & LL lobectomy \\
\hline 5. & R.O. & M & 60 & + & - & $\begin{array}{c}\text { Pneumonia like } \\
\text { (Irregularly mottled) }\end{array}$ & L Pneumonectomy \\
\hline 6. & F.I. & $\mathrm{F}$ & 55 & - & - & $\begin{array}{l}\text { Circular and } \\
\text { well circumscribed }\end{array}$ & RL lobectomy \\
\hline 7. & M.S. & $\mathrm{F}$ & 51 & - & - & $\begin{array}{c}\text { Pneumonia like } \\
\text { (Diffuse consolidation) }\end{array}$ & LU lobectomy \\
\hline 8. & M.U. & M & 51 & - & Cough & $\begin{array}{l}\text { Multicentric } \\
\text { and patchy }\end{array}$ & $\begin{array}{l}\text { Open lung } \\
\text { biopsy }\end{array}$ \\
\hline 9. & S.M. & $\mathrm{F}$ & 43 & - & $\begin{array}{l}\text { Bloody } \\
\text { sputum }\end{array}$ & $\begin{array}{c}\text { Pneumonia like } \\
\text { (Diffuse consolidation) }\end{array}$ & $\mathrm{R}$ pneumonectomy $* * *$ \\
\hline 10. & H.T. & M & 74 & + & $\begin{array}{l}\text { Bloody } \\
\text { sputum }\end{array}$ & $\begin{array}{c}\text { Pneumonia like } \\
\text { (Irregularly mottled) }\end{array}$ & $\mathrm{R}$ pneumonectomy $* * *$ \\
\hline 11. & M.O. & $\mathrm{F}$ & 42 & + & - & $\begin{array}{c}\text { Pneumonia like } \\
\text { (Irregularly mottled) }\end{array}$ & RU lobectomy \\
\hline 12. & M.K. & M & 68 & - & Chest pain & $\begin{array}{c}\text { Pneumonia like } \\
\text { (Diffuse consolidation) }\end{array}$ & LL lobectomy \\
\hline 13. & I.I. & $\mathrm{M}$ & 65 & + & Fever & $\begin{array}{c}\text { Pneumonia like } \\
\text { (Irregularly mottled) }\end{array}$ & RU\&M lobectomy \\
\hline 14. & T.M. & $\mathrm{F}$ & 60 & - & - & $\begin{array}{l}\text { Circular and } \\
\text { well ciecumscribed }\end{array}$ & LU lobectomy \\
\hline 15. & H.O. & $\mathrm{F}$ & 66 & - & Cough & $\begin{array}{l}\text { Circular and } \\
\text { well circumscribed }\end{array}$ & LU lobectomy \\
\hline 16. & T.T. & $\mathrm{M}$ & 41 & + & - & $\begin{array}{l}\text { Circular and } \\
\text { well circumscribed }\end{array}$ & RU lobectomy \\
\hline 17. & T.M. & M & 67 & + & - & $\begin{array}{c}\text { Circular and } \\
\text { well circumscribed }\end{array}$ & LU lobectomy \\
\hline 18. & T.U. & $\mathrm{M}$ & 60 & + & - & $\begin{array}{c}\text { Circular and } \\
\text { well circumscribed }\end{array}$ & RL lobectomy \\
\hline
\end{tabular}

\begin{tabular}{cll}
\hline$*$ & $\mathrm{M}:$ Male, & $\mathrm{F}:$ Female \\
$* *$ & $\mathrm{R}:$ Right, $\quad \mathrm{L}:$ Left, $\quad \mathrm{U}:$ Upper, \\
$* * *$ & RM\&L lobectomy following RU lobectomy
\end{tabular}

（3）気管支造影抢よび気管支鏡所見

全例に対して気管支造影および気管支鏡を施 行し，気管支造影に扔いて4 例の誘導気管支に 末梢の造影不良像あるいは中断像がみとめられ， 残り10例では異常所見がなく，本症の占拠部位 が肺末梢であるためと考えられた。匃管支鏡所 見では， 3 例が出血，外圧性狭窄等の間接所見 を呈し，1例に腫瘍の浸潤がみとめられ，残り
M: Middle, L: Lower

14例は無所見であった。

(4) 臨床細胞学的所見

1976年以降の8 例の細胞診成績をみると, 喀 痰細胞診では 3 例が, 擦過細胞診では 4 例が陽 性で, 腺癌と判定していた。しかし，標本を再 検討した結果, 腫瘍細胞が標本上に出現してい たにも拘らず，細胞の異型がそしいため䛊㓌性 となった症例があり，喀痰細胞診では㓌性 5 例 
Fig. 1. Chest X-ray film of case 2 shows a pneumonia like consolidation in the right lower lung field. The lesion is homogenous and well-defined without elevation of the right diaphragm.

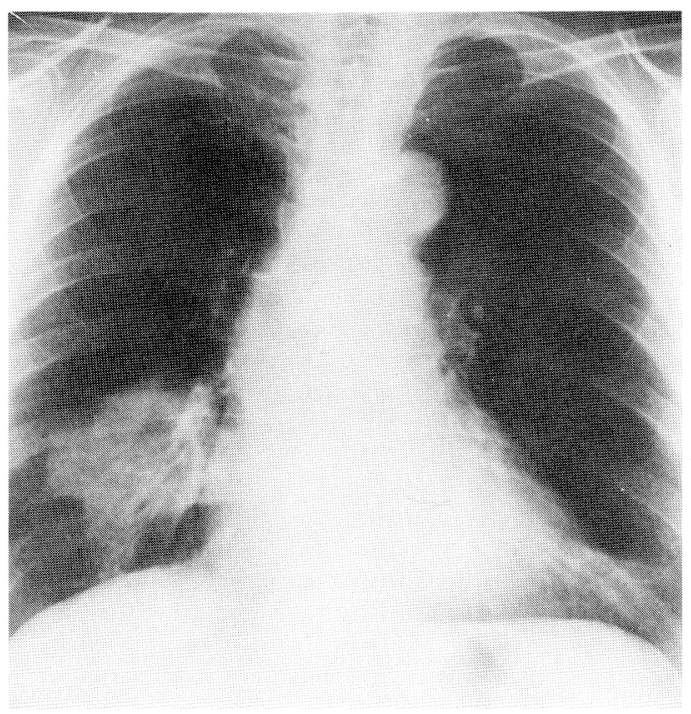

Fig. 3. Chest X-ray film of case 15 shows a circular and well circumscribed shadow in the left upper lung field with radiation of line shadow.

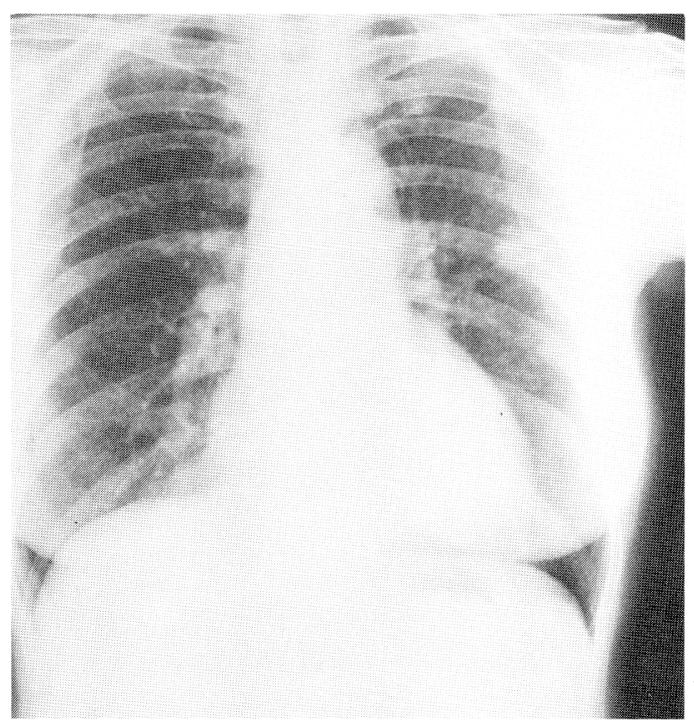

中 3 例が，擦過細胞診では㓌性４４例すべてが， 本来杜陽性と子べきものであることが知放たた。 とりわけ擦過細胞診では全例に，表2の如く特
Fig. 2. Chest X-ray film of case 13 shows a pneumonia like shadow in the right upper lung field. The lesion is illdefined, irregularly mottled, and hazy.
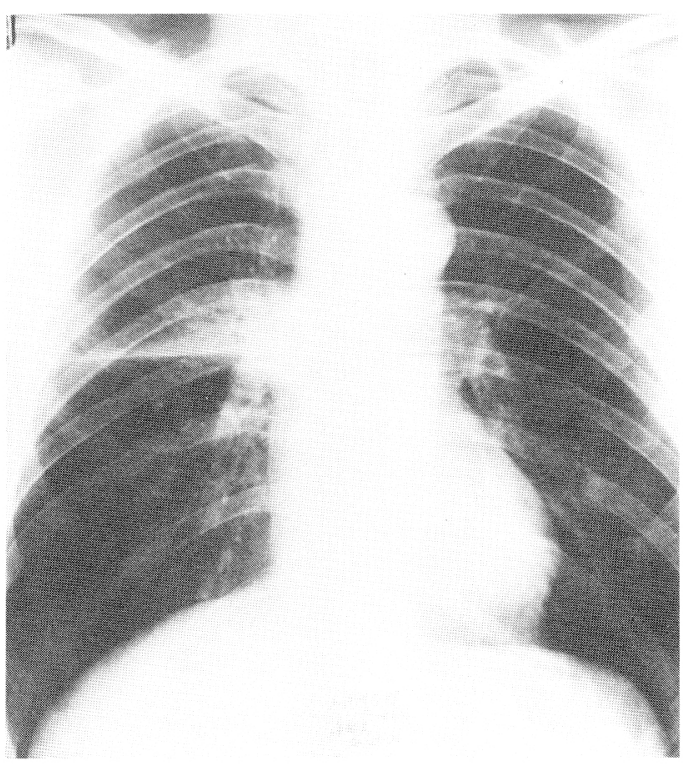

Fig. 4. Chest X-ray film of case 8 shows multicentric and patchy shadows scattered over the bilateral lung fields.
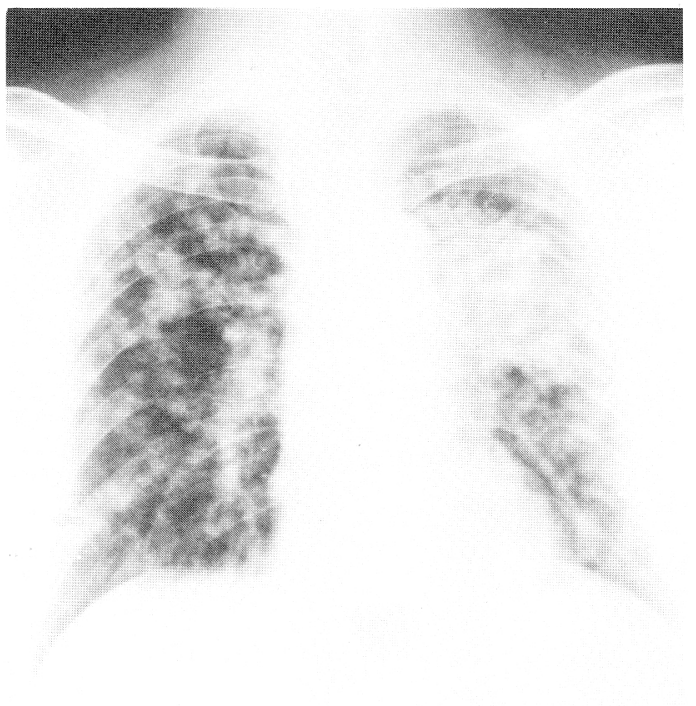

徵的な細胞集団がみられた。

（5）手術久式㧍上び价眼的所見

手術久式は，肺剔除術が1例で，肺葉切除術 
Table 2. Cytological features in bronchial brushings in 8 cases with bronchiolo-alveolar cell carcinoma, with special emphasis on tumor cell clusters.

\begin{tabular}{|c|c|c|c|c|c|c|}
\hline \multirow[b]{2}{*}{ Case } & \multicolumn{4}{|c|}{ Tumor cell clusters* } & \multirow{2}{*}{$\begin{array}{c}\text { Brush } \\
\text { border }\end{array}$} & \multirow{2}{*}{$\begin{array}{l}\text { Mucin in } \\
\text { cytoplasm }\end{array}$} \\
\hline & I & II & III & IV & & \\
\hline 2 & ++ & + & + & + & + & ++ \\
\hline 3 & ++ & + & + & + & + & ++ \\
\hline 4 & + & + & + & + & - & ++ \\
\hline 11 & ++ & - & ++ & + & - & + \\
\hline 12 & + & - & - & ++ & - & \pm \\
\hline 16 & + & - & - & + & + & \pm \\
\hline 17 & + & + & + & - & - & + \\
\hline 18 & ++ & - & - & + & - & \pm \\
\hline
\end{tabular}

I: Single-layer clusters along one-dimentional plane, in which cell circumference are smooth and/or dented.

II: Solid multi-layered cell cluster exhibiting distinct cell boundaries and abundant cytoplasm, conforming to a tortoise shell or honeycomb pattern.

III: Solid multi-layered cell cluster surrounded by amorphous mucin in which the cluster appears floating.

IV: Solid multi-layered cell cluster conforming to a pattern similar to a bunch of grapes.

Fig. 5. Histology of case 2, H\&E stain, X100. Tall columnar and uniform cells grow along the thin alveolar framework. The nuclei are basally placed and slight in atypism. The cytoplasm is abundant in volume, which resembles those of goblet cells.

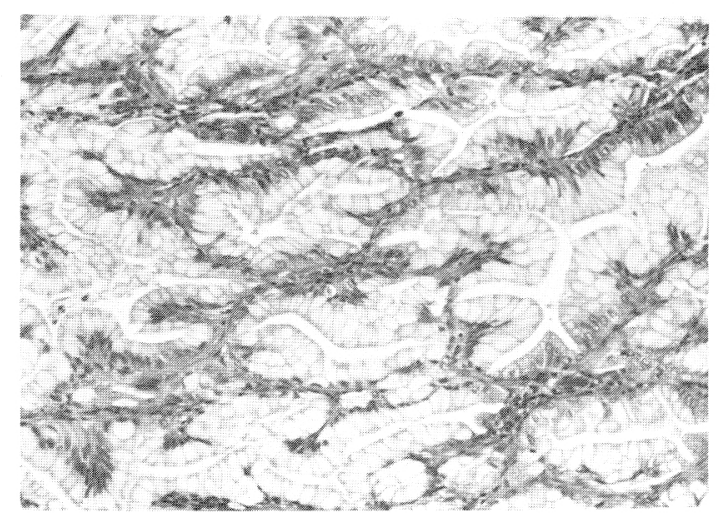

を行った16例のうち2 例は，局所再発のため同 側残存肺葉の再切除を行った。多発性結節性除 影を呈し，開胸肺生検を施行したものが 1 例亦 った。

切除肺の肉眼的所見は, 結節状の腫瘤を呈し たものが6例あり，ほぼ全例に胸膜陥山がみと
Fig. 6. Histology of case 7, H\&E stain, X100. Tall columnar cells are rich in cytoplasma and poor in nuclear chromatins. Vacuoles in cytoplasm is not apparent.

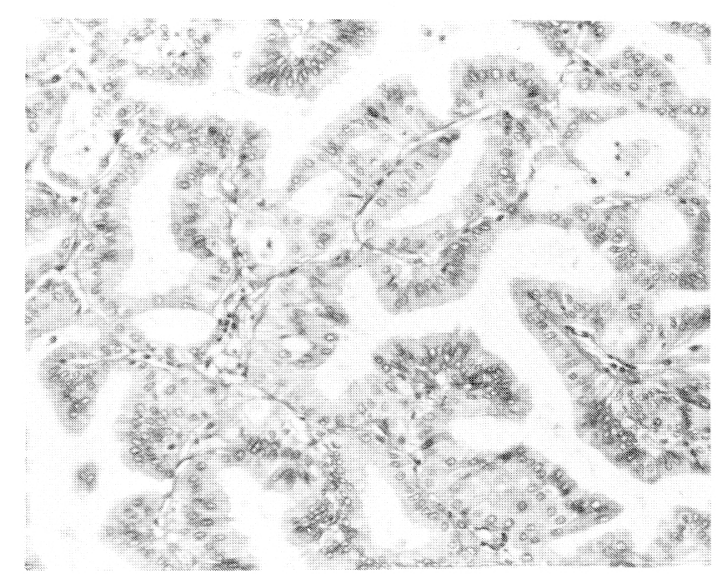

められた。粘液性かか浮腫状で比較的大きな弾 性軟の腫瘤を呈したものが 4 例，境界不明瞭な びまん性の硬結を呈したものが5例あった。

(4) 組織兴的所見

背丈がきわめて高い円柱状腫瘍細胞が，規則 正しく配列した症例が 8 例あった (図5，6）。個 
Fig. 7. Histology of case 2, PAS stain, X100. Note the strikingly stained PAS positive granules.

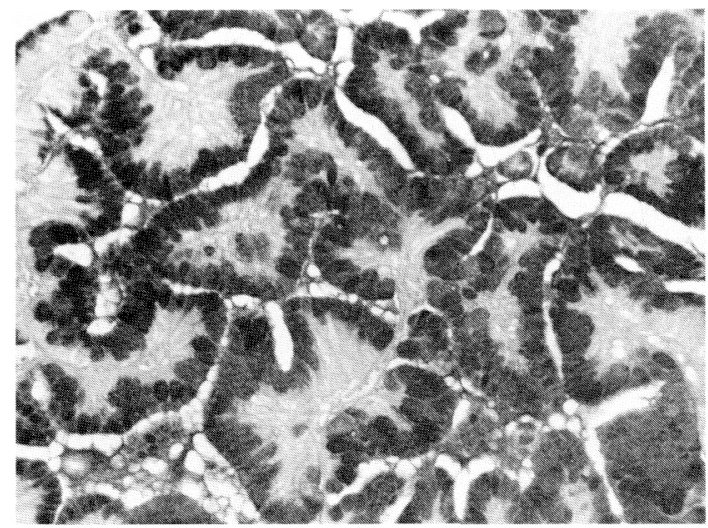

Fig. 9. Histology of case 13, H\&E stain, X100. Papillary structure is present in the frame work. The peg-shaped tumor cells are poor in nuclear chromatin and irregular in size.

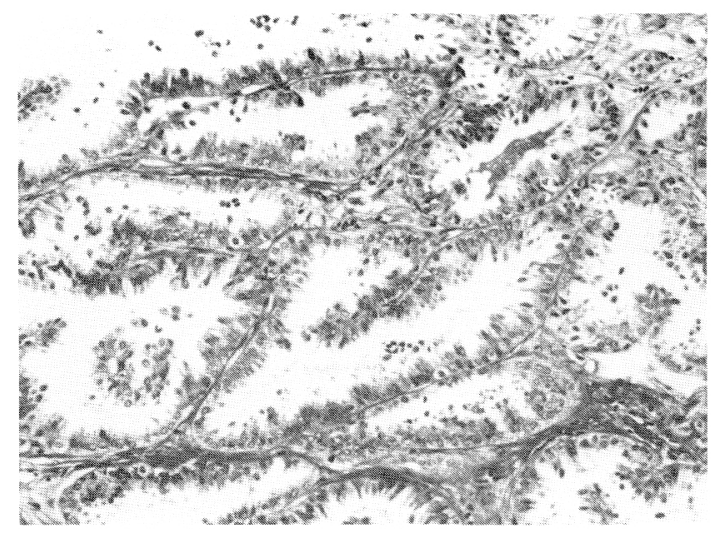

々の腫瘍細胞の自由縁は明䀢で連続性が保たれ， 刷毛縁有しているものも方った。核注細胞の 長軸方问に一致した楮円形で異型に巨しく間睤 側に並び，間質は既存肺胞の構築をきわかて良 好に保持し，弾性線維や膠原線雜の増生に上る 肥厚はみとめられなかった。これらのうち4例 は, 細胞啠内に粘液様物質が无满し, エ才ジン 好性は不良であるが，PAS，アルシアン青，么 チカルミン共に強陽性で，杯細胞に類似した形 態と考之ら狄た(図 5，7）。他の4例は細胞質の 工オジン好性が強く，粘液染色に対しても細胞 質の自由縁付近が染色される程度で(四6，8)軽
Fig. 8. Histology of case 7, PAS stain, X100. Note the poorly stained PAS positive granules.

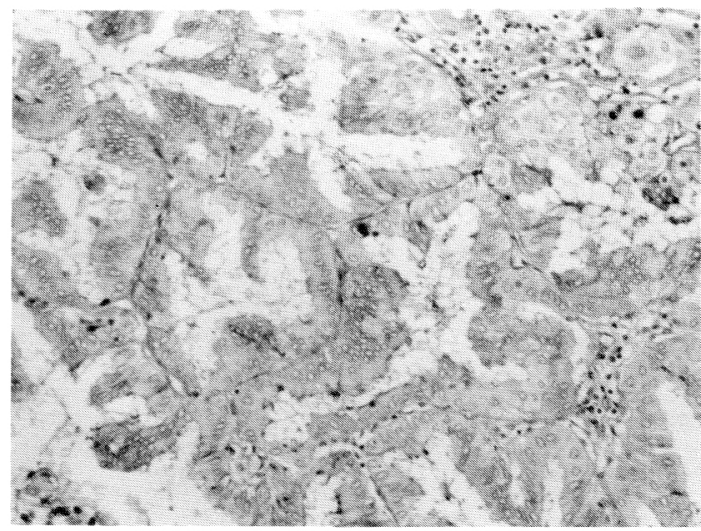

Fig. 10. Histology of case 15, H\&E stain X100. Cuboidal and/or peg shaped cells are less uniform in shape and marked in nuclear chromatin.

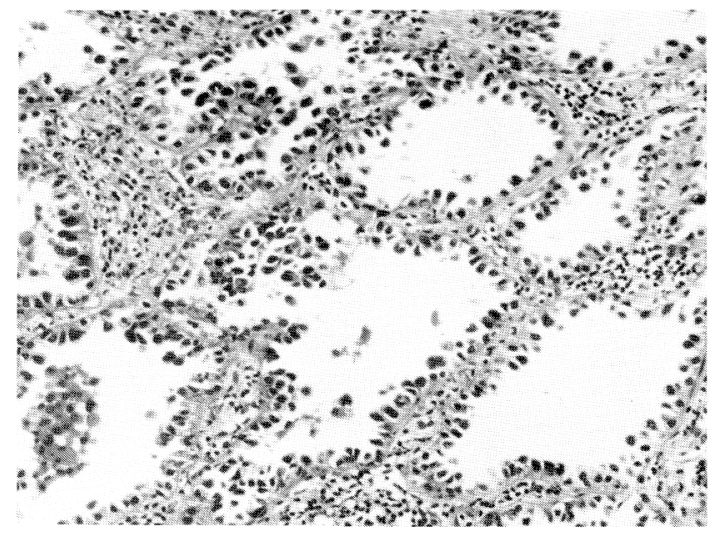

度の㤥異型のみられるものも㐫った。

一方，二机らに対して背丈が比較的低く，立 方状ないし“くい”状の腫湯細胞が，やや不揃 いに配列した症例が10例あった(四 9,10)。これ ら腫瘍細胞の細胞質はエオジンに好染し, 粘液 染色には好染しないものが多く，自由縁に連続 性がみとめられなかった。細胞の多形性や核異 型が比較的高度な症例が散見された。10例中 5 例は結節性増殖を呈し，間所の弾性線維㧍よび 膠原線維が增生して肥厚した部分や，それに併 い腫瘍実質が圧排され，やや不明睹となったと ころもみとめられたが，明瞭な瘢痕形成に至っ 
Table 3. Extent of nodal involvement and pleural invasion in 18 cases with bronchiolo-alveolar cell carcinoma

\begin{tabular}{lcccccc}
\hline $\begin{array}{c}\text { Extent of nodal } \\
\text { involvement }\end{array}$ & None & $\begin{array}{c}\text { Intra- } \\
\text { pulmonary }\end{array}$ & Hilar & Mediastinal & $\begin{array}{c}\text { Extra- } \\
\text { thoracic }\end{array}$ & $\begin{array}{c}\text { Undeter- } \\
\text { mined }\end{array}$ \\
\hline No. of cases & 12 & 1 & 2 & 1 & 0 & 2 \\
\hline $\begin{array}{l}\text { Pleural } \\
\text { invasion }\end{array}$ & None & $\begin{array}{c}\text { Within } \\
\text { visceral pleura }\end{array}$ & $\begin{array}{c}\text { Penetrating through } \\
\text { Visceral pleural }\end{array}$ & $\begin{array}{c}\text { Chest wall } \\
\text { invasion }\end{array}$ \\
\hline No. of cases & 7 & 9 & 0 & 2
\end{tabular}

Table 4. Extent of the tumor in 18 cases with bronchioloalveolar cell carcinoma by the shape of tumor cells

\begin{tabular}{lccccc}
\hline $\begin{array}{l}\text { Shape of } \\
\text { tumor cells }\end{array}$ & $\begin{array}{c}\text { No. of } \\
\text { cases }\end{array}$ & $\begin{array}{c}\text { Nodal } \\
\text { involvement }\end{array}$ & $\begin{array}{c}\text { Pleural } \\
\text { invasion }\end{array}$ & $\begin{array}{c}\text { Blood vessel } \\
\text { invasion }\end{array}$ & $\begin{array}{c}\text { Intrapulmonary } \\
\text { metastasis* }\end{array}$ \\
\hline \begin{tabular}{l} 
Tall columnar \\
\hline $\begin{array}{l}\text { Cuboidal and/or } \\
\text { peg shaped }\end{array}$
\end{tabular} & 10 & 1 & 3 & 2 & 2 \\
\hline
\end{tabular}

* On postoperative X-ray films

たものはみられなかった。他の5例は浸潤性増 殖を呈して肺組織を広汎に浸潤し，そのうち 2 例は臓側刻膜を越えて進展していた。

リンパ節転移は稀で，また，全例において腫 瘍が胝膜に隣接するまで増殖し，11例に明らか な侵襲がみとめら狄た(表 3 ).

腫瘍細胞の背丈の高い群 8 例と, 背丈の低い 群10例の，リンパ節転移，朔膜侵襲，血管侵襲， 術後明らかとなった肺内転移を比較すると, 後 者の方が, 腫瘍の拡がりが大であった(表 4 ).

(7) 予後

手術後経過年数の短い症例を含めて予後をみ ると, 再発, 転移による死亡が7例あり, 全例 に肺内転移がみとめられた。そのうち4例は, 対側肺および両側肺に多数の転移巣がみられた。 脳転移，脊椎転移，およびリンパ節転移が各 1 例あった。また，初回手術後に局所再発をきた し，再手術による直接死亡が 1 例あった。これ ら 8 例の平均生存期間は 12 个月であった。

各症例の予後を, 肉眼的所見, 組織学的所見, TNM分類 ${ }^{2)}$ による病期, 合併療法の有無別にみ ると(表 5 ), 再発, 転移による死亡は, 腫瘍細 胞の背丈の高いもの2 例に対して, 低いもので は6 例あった。背丈が高いものの中で，粘液染 色強陽性で，杯細胞様形態を呈した 4 例は，全
例術後再発がみられなかった。一方，背丈が低 いものの中で，組織学的に浸洲性㙕列! 呈した 5 例は, 術後 2 年以内に全例が，再発，転移の なめ死亡したが，結節性㙕列を呈した 5 例は 1 例を除き予後良好であった。

すなわち，切除予後不良のものは，大半が腫 瘍細胞の背丈の低い症例で占められ，そ狄に刘 して子後良好のものは，背丈が高く烃細胞様で あるが，背丈が低くても結節性增列を呈した場 合であった。

また，核異刑は概して軽度のものが多く，軽 度であっても予後不良のものもあれば，高度で あっても予後良好なものがあった。

\section{4. 考察}

Liebow $^{3)}$ により一応まとまった疾患概念とさ 狄た、いわゆる bronchiolo-alveolar cell carcinomaの频度は, 原発性肺瀘の0.5〜6.5\% $\%^{3)-5)}$ 占め，当施設においては切除ないし試験開䏫575 例中18例あり，約3.1\%である。

臨床像は，胸部レ線写真上多発性の陰影を呈 し䰻めて悪性の経過を辿るとしたもの ${ }^{6)}$ もあ狄 ば, 他方, benign pulmonary adenomatosisとして 本症の一部を良性疾患の如く扱うこと妾もある。 著者らの自験例の臨床像も単純ではなかった。 
自覚症状は原発性郝癌一般のそれと大差なく， 初診時 8 例に呼吸器症:状があり，10例は無症状 で，検診によって発見された。これまでに報告 されているような，多量の喀痰を主訴とする栋 例 $^{8), 9)}$ は, 今回の娭索刘象中にはなかった。

刖部レ線等真上，腫瘤状結節状㓌影を旱した 6 例は，境界鮮明で濃度の高い典型的な肺野刑! の㓌影で，切除標本の硬い結節状の腄瘤の投影 であり，全例が䏫膜妵下にあり䏫膜份山を随伴 していた。肺j炎様㓌影を旺した11例のうち4例 は漫㵎影を呈し，巡緣不明瞭でびまん性，濃度 は低くかつ不均質であった。切除憋本上これら の多くはびまん性の硬結を呈し，周囲の肺j組織 との境界が不明瞭であった。肺炎様陰影の残り 7 例は無父脚状影であり，濃度は均钼でややや低 く，境界は比較的明瞭であったが，肺門型肺渡 の父管支閉塞による肺葉あるいは肺域単位の 無父肺影とは異り，輪郭はむしろやや不規則で， 縦隔や横隔膜の偏位もなかった。これらの多く は腫瘍の肉眼的性状，すなわち割面が浮腫状で，

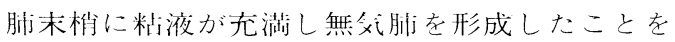
反映したものと推定された。

本症の診断には喀痰細胞診が有用であるが(10) 13) 他の肺腺摛との鑑別が困難なことがある他に， ときには良性のいわ吼腺様增生細胞との鑑別 が困難で，誤㓌性となることもあり注意を要す

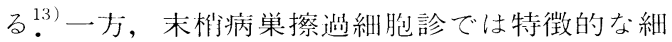
胞集団が出現し(表2)，これらにより許陰性を 避け得るばかりでなく，積嫩的に本症をを推定す ることが可能と考えられた。詳絊は著者らが既

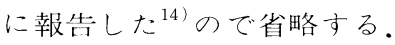

本症は組織像によって進展の程度抢よび臨床 像に差異がみられたことは既述の如くである。 こ扎らを組織像上, 腫瘍細胞の背丈の高い症例 は, 粘液染色強陽性で杯細胞様の群と, 粘液染 色に好染しない群に，北丈の低い立方状ないし “くい”状の症例は，汶娍性に增列する群と結節 性に增列する群の，計 4 群に大別して検討した。

背丈が商く杯細胞様の群は, 間翼の肥厚はな く, レ線字真上肺炎様㓌影(無父朋状影) を呈し, 肉眼的に粘液が冭满し浮腫状で，大きな腫瘤を 形成するにもかかわらず，腫湯の進展は軽度で
あり，切除子後は舆好であった。

北文が高く䊀液染色に好染しない群は、レ線 号真所見ならびに肉眼所見上特徽がみられず，

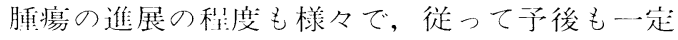
した傾们がみられなかった。

北丈が低く渗洞性:增列を是古る群は，粗液染 色に好染せず，間所の肥厚は軽度であることが

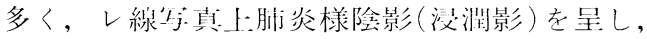
肉眼的にはびまん性かつ㙏界不明瞭な硬結で, 腄演は高度に進展してきわ力て子後不垦であっ た。

北丈が低く結節性增列壬を呈する群は，粘液染

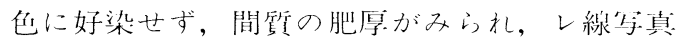
上でも肉眼的にも婳瘤状の結節で䏫膜陷凹を伴 い, 冽膜信襲のある症例も多いが，铰径 $3 \mathrm{~cm}$ 以 下の症例が半数あり，予後は比較的衰好であっ た。

bronchiolo-alveolar cell carcinomaをレ線上 抢よび外科病理学的観圤から若干のグループに 分類しようとする試みが報告されているが(15) -17) 著者的の蚞索に执いても以上のように，いくつ かのグループが存在していることが示唆された。

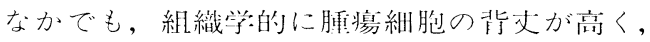
粘液染色強陽性:で，杯紐胞様の4例は，きわめ て類似した形態，臨床所見，切除予後を有古る 一群であると将えられる。

したがって, 臨床上, 本症と診断しても, 更 に詳細な組織学的背景を考慮することが, 予後 を侤える上で重要である。切除前にこれらを適 確に推定することは困難と思われるが, レ線写 真所見および擦過細胞診所見の解析を充分に行 うことが必要であり，可能であれば経気管支肺 生検が，これらを知る上で有効と都えられる。

\section{5. 結 論}

以上の検索により次の結論を得た。

（1）本症は比較的特徵的なレ線写真像を呈すも のが多く，大半は擦過細胞診から診断し得る。

（2）腫瘍細胞の背丈が高く，杯細胞様の症例の 切除子後は良好である。

（3）背丈が低く浸潤性㙼殖を示方症例は，切除 してもきわめて子後不良である。 
Table. 5 Pathological findings and prognosis of 18 cases with bronchiolo-alveolar cell carcinoma

\begin{tabular}{|c|c|c|c|c|c|}
\hline \multirow[b]{2}{*}{ Group* } & \multirow[b]{2}{*}{ Case } & \multirow[b]{2}{*}{ Gross appearance } & \multicolumn{3}{|c|}{ Microscopic findings } \\
\hline & & & $\begin{array}{l}\text { Shape of } \\
\text { tumor cells }\end{array}$ & $\begin{array}{l}\text { Nuclear } \\
\text { atypism }\end{array}$ & Mucin \\
\hline \multirow{4}{*}{ A } & 1 & $\begin{array}{l}\text { Diffuse and soft mass } \\
\text { packed with mucous }\end{array}$ & $\begin{array}{l}\text { Tall columnar } \\
\text { (Goblet cell like) }\end{array}$ & \pm & ++ \\
\hline & 2 & $\begin{array}{l}\text { Diffuse and soft mass } \\
\text { packed with mucous }\end{array}$ & $\begin{array}{l}\text { Tall columnar } \\
\text { (Goblet cell like) }\end{array}$ & \pm & ++ \\
\hline & 3 & $\begin{array}{l}\text { Diffuse and soft mass } \\
\text { packed with mucous }\end{array}$ & $\begin{array}{l}\text { Tall columnar } \\
\text { (Goblet cell like) }\end{array}$ & \pm & ++ \\
\hline & 4 & $\begin{array}{l}\text { Diffuse and soft mass } \\
\text { packed with mucous }\end{array}$ & $\begin{array}{l}\text { Tall columnar } \\
\text { (Goblet cell like) }\end{array}$ & \pm & ++ \\
\hline \multirow{4}{*}{ B } & 5 & $\begin{array}{l}\text { Diffuse and elastic } \\
\text { hard mass }\end{array}$ & Tall columnar & ++ & \pm \\
\hline & 6 & $\begin{array}{l}\text { Nodal mass with } \\
\text { pleural indentation }\end{array}$ & Tall columnar & \pm & + \\
\hline & 7 & $\begin{array}{l}\text { Diffuse and elastic } \\
\text { hard mass }\end{array}$ & Tall columnar & \pm & \pm \\
\hline & 8 & $\begin{array}{l}\text { Multiple nodules } \\
\text { packed with mucous }\end{array}$ & Tall columnar & \pm & + \\
\hline \multirow{5}{*}{ C } & 9 & $\begin{array}{l}\text { Diffuse and } \\
\text { ill-defined mass }\end{array}$ & $\begin{array}{l}\text { Cuboidal and/or } \\
\text { peg shaped }\end{array}$ & + & \pm \\
\hline & 10 & $\begin{array}{l}\text { Diffuse and } \\
\text { ill-defined mass }\end{array}$ & $\begin{array}{l}\text { Cuboidal and/or } \\
\text { peg shaped }\end{array}$ & ++ & \pm \\
\hline & 11 & $\begin{array}{l}\text { Diffuse and } \\
\text { ill-defind mass }\end{array}$ & $\begin{array}{l}\text { Cuboidal and/or } \\
\text { peg shaped }\end{array}$ & ++ & + \\
\hline & 12 & $\begin{array}{l}\text { Diffuse and ill-defind } \\
\text { mass infiltrating to } \\
\text { the rib }\end{array}$ & $\begin{array}{l}\text { Cuboidal and/or } \\
\text { peg shaped }\end{array}$ & \pm & + \\
\hline & 13 & $\begin{array}{l}\text { Diffuse and ill-defind } \\
\text { mass infiltrating to } \\
\text { the adjacent lobe }\end{array}$ & $\begin{array}{l}\text { Cuboidal and/or } \\
\text { peg shaped }\end{array}$ & \pm & \pm \\
\hline \multirow{5}{*}{ D } & 14 & $\begin{array}{l}\text { Nodal mass with } \\
\text { pleural indentation }\end{array}$ & $\begin{array}{l}\text { Cuboidal and/or } \\
\text { peg shaped }\end{array}$ & ++ & \pm \\
\hline & 15 & $\begin{array}{l}\text { Nodal mass with } \\
\text { pleural indentation }\end{array}$ & $\begin{array}{l}\text { Cuboidal and/or } \\
\text { peg shaped }\end{array}$ & + & + \\
\hline & 16 & $\begin{array}{l}\text { Nodal mass with } \\
\text { pleural indentation }\end{array}$ & $\begin{array}{l}\text { Cuboidal and/or } \\
\text { peg shaped }\end{array}$ & + & \pm \\
\hline & 17 & $\begin{array}{l}\text { Nodal mass with } \\
\text { pleural indentation }\end{array}$ & $\begin{array}{l}\text { Cuboidal and/or } \\
\text { peg shaped }\end{array}$ & + & + \\
\hline & 18 & $\begin{array}{l}\text { Nodal mass with } \\
\text { pleural indentation }\end{array}$ & $\begin{array}{l}\text { Cuboidal and/or } \\
\text { peg shaped }\end{array}$ & + & \pm \\
\hline
\end{tabular}

* A: $\quad$ Cases of tall columnar cells with ample mucin (Goblet cell like).

B: $\quad$ Cases of tall columnar cells without ample mucin.

C: $\quad$ Cases of cuboidal and/or peg shaped cells with infiltrative growth.

D: $\quad$ Cases of cuboidal and/or peg shaped cells with nodal growth. 


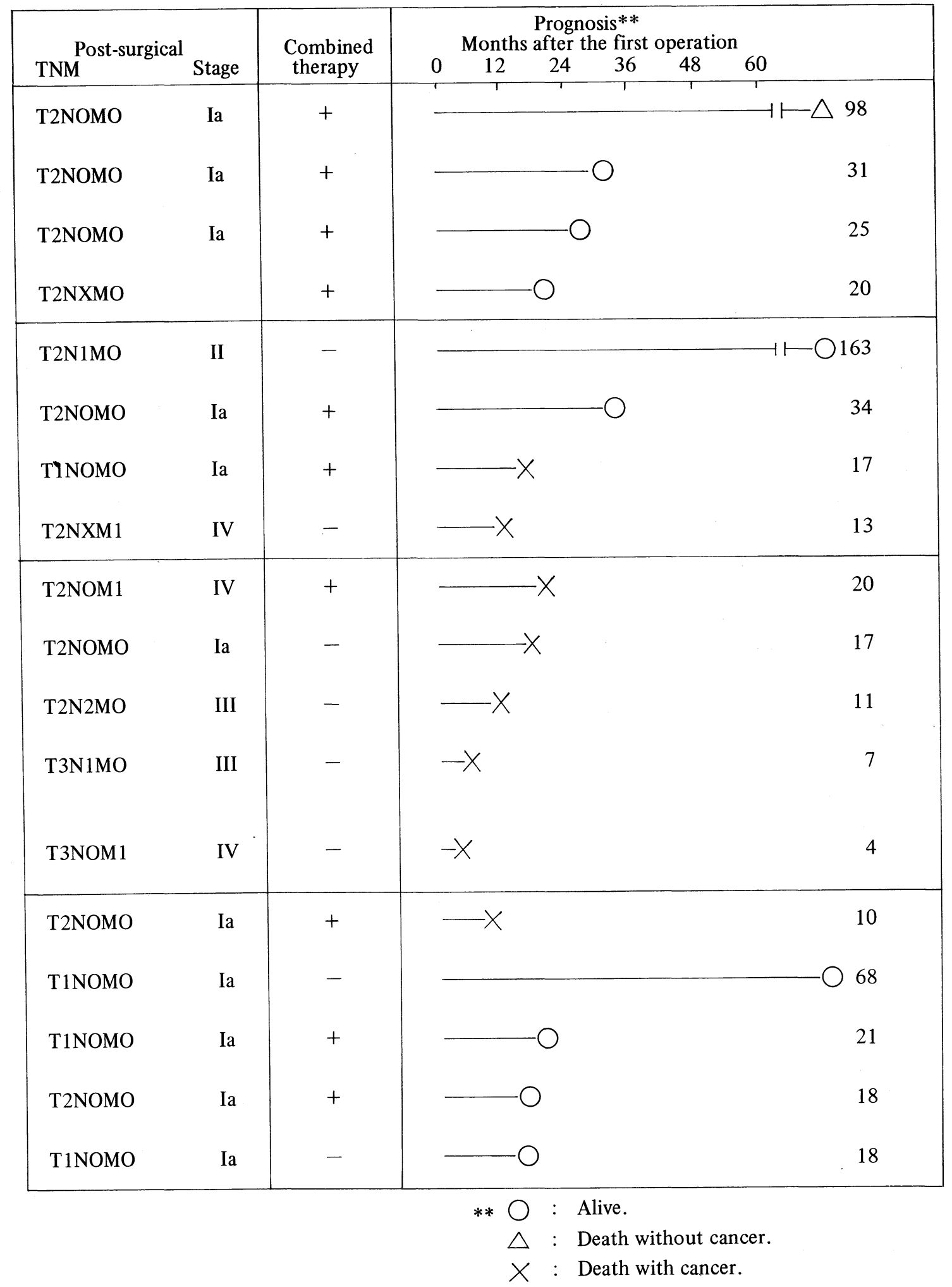


（4）背丈が低くても，結節性增列を示守症例は， 比較的予後良好である。

\section{文}

1) Kreiberg, L.: Histological typing of lung tumors, WHO, Geneva, 1967.

2) Harmer, M.H. : TNM classification of malignant tumours, 3rd ed., UICC, Geneva, 1978.

3) Liebow, A. A. : Advances. Intern. Med., 10 : 329, 1960.

4) Storey, C. F., Knudtson, K.P., and Lawrence, B. J. : J. Thorac. Surg., 26:331, 1953.

5) Watson, W.L., and Farpour, A.: Cancer, $19: 776,1966$.

6) Delarue, N.C., and Graham, E. A.: J. Thorac. Surg., $18: 237,1949$.

7) Spencer, H.: Pathology of the lung, 3rd ed.: 826, Pergamon Press, Oxford, 1977.

8) Kennamer, R.: JAMA, 145:815, 1951.

9) Homma, H. , Takahashi, Y., and Imai, H.:Amer. Rev. Resp. Dis., 111: 857, 1975.

10) Mears, T. W., Kirklin, J. W., and Woolner, L. B.:
本稿の要旨は, 第19回日本肺湤学会総会で発 表した。
J. Thorac. Surg., 27:420, 1954.

11) Delarue, N.C., Anderson, D., Sanders, D., and Starr, J.: Cancer, 29: 90, 1972.

12) Roger, V., Nasiell, M., Linden, M., and Enstad, I.: Acta Cytol., 20:303, 1976.

13）沢田勤也・福間誠吾・関 保雄 - 石田逸郎 - 池 田栄雄・土屋信子・小栗孝志・田中昇：日臨 細胞誌，18：155，1979.

14）斎藤泰紀・アヌサク・ジェンプルクサワン・赤荻 栄一・須田秀一一佐藤博俊, 橋本邦久 - 仲田 祐：日臨細胞誌，18：147，1979.

15) Marco, M., and Galy, P.: Amer. Rev. Resp. Dis., $107: 621,1973$.

16) McNamara, J. J. et al : J. Thorac. Cardiovasc. Surg., $57: 648,1969$.

17) Munnell, E.R., Lawson, R. C., and Keller, D. F.: J. Thorac. Cardiovasc. Surg., $52: 261$, 1966. 


\title{
Bronchiolo-alveolar Cell Carcinoma of the Lung - A Clinicopathological Study —
}

\author{
Yasuki Saito, Yuzuru Amano, Anusak Yiengprugsawan, Eiichi Akaogi, \\ Hideichi Suda, Hirotoshi Sato, Kunihisa Hashimoto, and Tasuku Nakada
}

\author{
Department of Surgery, The Research Institute for Chest Diseases and \\ Cancer, Tohoku University, 4-1 Seiryomachi, Sendai, 980 Japan
}

A series of 18 cases of operated bronchiolo-alveolar cell carcinoma of the lung is reviewed clinicopathologically.

Sputum cytology and bronchial brushing are available for properative diagnosis with special emphasis on bronchial brushing.

Chest $\mathrm{x}$-ray and surgico-pathological findings revealed various patterns.

They are summerized in 4 histological groups as follows.

Gourp A presents tall columnar cells with ample much which are similar to goblet cells.

Group B presents tall columnar cells without ample mucin.

Group C presents cuboidal and/or peg-shaped cells with infiltrative growth.

Group D presents cuboidal and/or peg-shaped cells with nodal growth.

Cases of group A characteristically showed a diffuse consolidation on chest $\mathrm{x}$-ray film, and postsurgical prognosis are favourable.

Case of group $\mathrm{C}$ showed an ill-defined and irregularly mottled shadow on chest $\mathrm{x}$-ray film, and all of them died within 2 years after operation even if nuclear atypism of some cases were slight. 